live better lives? The answer will surely not be in the possession of a single discipline.

A. MacMillan

\title{
Effectual Entrepreneurship
}

- Read, S., Sarasvathy, S., Dew, N., Wiltbank, R. and Ohlsson, A.-V. (2011), Effectual Entrepreneurship, paperback, Routledge, pp. 228.

'Success in investing doesn't correlate with IQ-once you're above the level of 125. Once you have ordinary intelligence, what you need is the temperament to control the urges that get other people into trouble in investing.

Warren Buffett

\section{Introduction}

The promotion of entrepreneurship has been a major worldwide policy target, as it is thought to be associated with the creation of wealth, technological innovation and increased social welfare. The literature has suggested that entrepreneurial entry is the outcome of ability to identify and exploit opportunities and motivation (Shane, 2004). Both elements are important in the decision to start a business. In this exciting new book, RSDWO effectively address issues which are ultimately related to entrepreneurial motivation, by presenting the main principles of effective entrepreneurship. The authors challenge some of the stylised facts of the entrepreneurship literature which often attribute mythical proportions to the figure of the entrepreneur and conclude by presenting principles of action and control based on sets of facts stemming from the behaviour of expert entrepreneurs. Pivotal to the discussion is the key distinction between effectual entrepreneurs, who work with means, as opposed to causal entrepreneurs who tend to work with goals, in the spirit of a search and select approach in business venturing. This reminds of the famous exploration versus exploitation distinction in organisational science (March, 1991). In the often conflicting processes of organisations, exploration deals with dynamic efficiency (searching for new options, experimenting and conducting research), while exploitation deals with static efficiency (refining existing procedures, doing the same things only better and reaping value from what is already known). RSDWO's effectual entrepreneurs engage in creative processes based on: (a) Who they are (traits, tastes, abilities); (b) What they know (education, training, expertise, experience) and (c) Who they know (social and professional networks). Based on these principles, the main aim of expert (effectual) entrepreneurs is to control and shape the future rather than try to predict, in contrast to novice (causal) entrepreneurs who perceive their ability to control the future, based on the extent that they can predict it. Based on these notions, the authors promise and depart on an exciting journey that intends to build on the motivation of latent and existing entrepreneurs by reviewing most foundational research and establishing patterns described as common practice among expert entrepreneurs across industries, regions and time. The first part of the book (Chapters 1-8) sets the background stage by challenging some 
of the main myths of entrepreneurship research, such as that entrepreneurs see opportunities others can't see, seize them faster, make better predictions than others, are brash risk-takers and different from the rest of the population, inter alia. The second part of the book (Chapters 9 to 18) puts forth the main principles of effectual entrepreneurship, i.e. (a) Start with own means (what is readily available, without waiting for the perfect opportunity); (b) Set affordable loss; (c) Leverage contingencies (i.e. embrace surprises); (d) Form partnerships; (e) Create opportunities. Finally, the third and last part (Chapters 19 and 20) concludes this exciting journey by addressing current entrepreneurs in the process of a growing venture and attending to questions of how far the venture can go. The next sections review the contents of the three parts of the book in greater detail.

\section{Part I: Myths and realities about entrepreneurial entry}

The study of entrepreneurship and innovation from a behavioural perspective has much in common with the Austrian-school analysis and the intellectual tradition of Schumpeter (1934) and Hayek (1945). Motivation and the ability to identify and exploit opportunities are the two key tenets of entrepreneurial orientation. Both the economics and management literature suggest that entrepreneurial entry is the outcome of several 'personality', or motivational, aspects, such as lower risk aversion (Kihlstrom and Laffont, 1979; Moskowitz and Vissing-Jörgensen, 2002), or higher optimism and overconfidence and lower ambiguity/skewness aversion (de Meza and Southey, 1996; Camerer and Lovallo, 1999; Bernando and Welch, 2001; Astebro, 2003). Finally, recent studies present interesting inquiries attributing a genetic component of entrepreneurial talent (Nikolaou, et al., 2008) and risk-taking (Cesarini, et al., 2009), in the spirit of Baumol's (1990) fixed pool of such talent. Hence, entrepreneurs are often claimed to be different from non-entrepreneurs, by, for example, being less risk averse, less ambiguity averse and more overconfident. In the first part of the book, RSDWO challenge this narrow view, without necessarily refuting all aspects of this foundational behavioural research, but rather refocusing on the aspects of uncertainty and control.

Chapter 1 challenges the common view that entrepreneurs are unique visionaries, presenting the fundamentals of effectual versus causal logic. In the spirit of Schumpeter (1934), it concludes with the effectual premise that many opportunities can be created, rather than discovered and new markets can often be viewed as a residual, explored via creative and transformative tactics. Chapter 2 questions the 'eureka' moment view of entrepreneurial pure vision, by presenting some unique case studies of successful and radical business change (Colgate, Tiffany, Nokia, One True Media, De Witt, inter alia). These challenge the narrow view of innovative ideas and stress the role of commitment, along with opportunity. Chapter 3 reviews the common assertion that entrepreneurs are risk-takers, pointing out that expert entrepreneurs are dealing with uncertainty rather than risk. A comparative study of differences in the stated preferences of entrepreneurs and bankers is presented, pointing to the latter assertion. Without refuting the risk-taking evidence, RSDWO conclude that uncertainty can be transformed into opportunity by controlling the environment and effectuation principles can provide unique sets of 
heuristics which are related to control. Chapter 4 challenges the famous liquidity constraint story, which is typically viewed as the greatest impediment to start-ups and successful venturing. The recent literature which casts serious doubt on the role of wealth, instrumented or not, on entrepreneurship is reviewed (Hurst and Lusardi, 2004; inter alia). Based on effectual logic, RSDWO conclude that having nothing can be viewed as an advantage instead of disadvantage if it serves as motivation to minimise losses, invokes learning and creativity, along with the formation of partnerships, etc. ${ }^{1}$ Then, Chapter 5 questions the view that entrepreneurs are unique forecasters, pointing out that control rather than prediction is the keyword for entrepreneurial behaviour. ${ }^{2}$ The authors emphasise the adaptation and learning capabilities of expert entrepreneurs, along with partnerships as key components of a more proactive effectual and strategic approach to the environment, in a world where dynamic capabilities are pivotal. The chapter concludes that in uncertain situations, control can be achieved by constructing elements of the environment in which one can build their venture.

Chapter 6 discusses the start-up decision, emphasising that the actual moment of taking the plunge is mostly a matter of motivation (this covers all cases from serendipity and necessity up to aspiration). The anatomy of the plunge decision is presented in detail (p. 48) along with exciting case studies of individual circumstances. The conclusion of the chapter is that 'action trumps analysis'. Chapter 7 challenges the view that entrepreneurs are different from the rest of the population and 'unique' creatures, stressing that what can really make the difference is effectual thinking as a different way of looking at the world. Literature that emphasises the role of education as the biggest source of success, independent of parental occupation and other characteristics is reviewed. ${ }^{3}$ The authors describe expert successful entrepreneurs as an unexpected combination of persistence and flexibility, that do not have an instrumental view of the world and work on making success happen rather than trying to avoid failure. Chapter 8 concludes this section by focusing on the fear of failure, stating that it is a subjective concept and presenting some interesting case studies of subjective failure (Apple, etc.). Interesting psychological research on the detrimental but transitory emotional impact of failure is reviewed (Shepherd, 2003) and the interesting fact that only $8 \%$ of the companies that close down owe money to their debtors is highlighted. The chapter concludes stating that: (a) it is a myth that failure is terminal; (b) failing alone is probably the biggest threat and (c) part of creating an entrepreneurial culture is celebrating failure, in the spirit of Baumol (1990).

\footnotetext{
${ }^{1}$ Interestingly, the authors describe sales as the noblest part of business, in contrast to many popular views by entrepreneurs and as a tool in the process of bootstrapping benefits and one's own business.

${ }^{2}$ RSDWO review the interesting behavioural entrepreneurship literature that suggests that entrepreneurs may be more likely to have a bad relationship with prediction, due to traits popularly labelled as overconfidence and excess risk-taking. The discussion is reviewing most of the relevant psychological aspects, stemming from concepts such as locus of control, the attribution theory, bounded cognition and isotropy.

${ }^{3}$ One needs to point out that there is also recent literature based on (quasi-)experiments showing small and insignificant effects of educational programs on the willingness to engage in entrepreneurial activities (Oosterbeek et al., 2010).
} 


\section{Part II: Effectuation in action}

In the second leg of this journey (Chapters 9 to 18), the authors get into the specific principles of effectual logic. Chapter 9 presents the first principle, according to which starting with means rather than goals helps one begin right away, with what they possess. This can also help avoiding fads. Chapter 10 emphasises the role of commitment in transforming an idea into a good concept. This helps to focus on the process of ongoing transformation and the principle of re-weighting emphasis on features or attributes of a product or market. ${ }^{4}$ Chapter 11 emphasises the affordable loss principle and how its use to reason through the start-up decision reduces the barriers, compared to the NPV approach, while it still manages risk. The conclusion is that starting is not about the upside being big enough, but about whether the downside is lifethreatening. Through that logic, the low survival rates of new entrepreneurs are less of a threat. ${ }^{5}$ Chapter 12 focuses on access to and the sources of finance, highlighting how in the effectual approach, investment is tightly coupled with the affordable loss principle. The pivotal control concept is based on the idea of doing the most with the least, in order to maintain control, and the authors suggest that bootstrapping can offer a better fit for most start-ups, which could avoid venture funding rather than pursue it. Chapter 13 focuses on social networking and partnerships (e.g. suppliers, customers, acquaintances), concluding that persuasiveness and rationality come together as commitment and 'buy-in is better than sellin'. ${ }^{6}$ RSDWO highlight the principle of effectual partnerships, i.e. that those who choose to join and self-select into the venture, ultimately make it what it is. This is in stark contrast to selecting partners to fit a given goal, which is the case with causal partnerships. Hence, the venture does not dictate the partnerships, but effectual partnerships create the venture. ${ }^{7}$ Chapter 14 discusses the tradeoffs between dimensions of ownership and control and the ideas of managing investors. The conclusion is that good partnerships make good ventures and that ownership enables alignment of incentives around the creation process. In both chapters, it is pointed out that larger units and organisations tend to become less effectual. Chapter 15 celebrates the role of the unexpected, providing examples of famous contingencies and stressing the confidence in one's own abilities to make the difference as a key component of effectual entrepreneurship. In the ample examples provided, the manner in which entrepreneurs leveraged the con-

4 An exciting hypothetical stated preference venturing experiment is presented in this chapter, focusing on these attributes of expert entrepreneurs.

${ }^{5}$ An interesting review of mental accounting is presented in this section (Thaler, 1985). However, another interesting concept that needed reviewing is loss aversion (Kahneman and Tversky, 1979; Tversky and Kahneman, 1991), which refers to people's tendency to strongly prefer avoiding losses to acquiring gains and can predict that affordable losses may be quite low, further hindering the plunge decision. Moreover, the discrepancy between ex ante stated and hypothetical preferences and ex post revealed preferences can also raise some scepticism with respect to setting realistic affordable losses ex ante.

6 The chapter contains excellent reviews of research on experimental economics for the importance of advice and word-of-mouth (p. 120) along with the social psychology of persuasion.

7 This is the 'crazy quilt principle', based on the metaphor of stitching together a patchwork quilt, rather than solving a jigsaw puzzle. 
tingencies provides the core of the authors' 'lemonade principle'. Expert entrepreneurs used contingencies as resources, thinking neither inside nor outside the 'shifting box', instead of providing purely adaptive or heroic responses. An interesting Chapter 16 emphasises on neglected aspects on the writing of business plans, such as the management of risk and the identification of real bottlenecks, based on the premise that 'one size does not fit all'. The chapter concludes that 'action succeeds planning'.

Chapter 17 accentuates the creation of venture identity, i.e. the 'persona' of the corporation in alignment with the business objectives. This comprises of the philosophy, the values, norms and the personality of the firm and its members, rather than a mere brand or logo. The conclusion is that identity is something that the effectual entrepreneur creates every day, as a reflection of what he/she stands for. Shaping this identity, reinforcing it through actions and communicating it effectively are central to the value creation of the firm. Finally, Chapter 18 highlights the power of non-predictive control; its effectual application means preference to work with elements where a significant contingency relationship exists between the entrepreneur and the element, as opposed to causal control techniques in which there is a low or no contingency relationship. Controlling the controllable by intervening, as a 'pilot on the plane', is the concluding principle of this part of the book.

\section{Part III: Entrepreneurial growth}

The third and final part of the book concludes this exciting journey by addressing current entrepreneurs in the process of a growing venture and attending to the question of how far the venture can go. Chapter 19 deals with effectual principles of optimal firm size that enables effectual control and emphasises on the role of innovation and the misconception that most SMEs are responsible for employment generation. ${ }^{8}$ Effectual management involves a fresh look, whereby 'Alexander the Great'-type mistakes are avoided by ensuring continuation and performance though selecting, promoting and training people inside a large firm, as well as thinking what might help entrepreneurs stay with the venture as it grows into a large firm. Chapter 20 concludes this beautiful journey in the nicest possible manner by addressing entrepreneurship as a technology for social change, married with the profit preoccupation, in stark contrast to the separation thesis. Within that view, entrepreneurship generates sustainable solutions to social problems, raising instruments and earning returns, while at the same time reducing the need for charity or higher taxes. Excellent examples, case studies and the main steps are described, along with an interesting section that compares the effectual entrepreneurship and the scientific method. The chapter's conclusion is beautifully outlined as the principle of 'doing what we ought; doing what we should'.

\section{Conclusion}

Overall, I have found this book to be the most motivating toolkit in the shelf of prospective and current entrepreneurs. It recommends a proactive attitude to

\footnotetext{
${ }^{8}$ For a review, the reader is referred to Shane (2008).
} 
business and life, based on exploitation of the environment, starting with the facts, one's own means, knowledge and networks. It views entrepreneurship as an effectual venture based on someone's own current facts. According to the authors, this book teaches that one need not wait for the right technology or the proper resources or the massive machinery of governments or the feeble hope of the next election to rebuild one's life and the world in which that life seeks to thrive. One can start today - with who they are, what they know and who they know - and invest nothing but what they can afford to lose, to begin building corridors through which their stakeholders can self-select into their valuable new venture. And together they can co-create value and societal welfare that neither could fully imagine at this point in time. The book addresses large audiences of students, scholars, latent and current (both denovo and family) entrepreneurs, offering an insightful new perspective on the study of entrepreneurship. This is achieved via the overview and critical evaluation of large bodies of recent literature from entrepreneurship, economics, management, finance and other related disciplines. This synthesis is presented in a unique non-technical way that makes the book a valuable handbook for individuals from all backgrounds with an interest in entrepreneurship as a discipline or as practice. The authors envisage the role of entrepreneurial education based on the view that entrepreneurship is not necessarily innate and this is exactly what they achieve: the production of a first class entrepreneurship education tool. Importantly, the authors hope that their explication of effectuation will become part of the mundane toolbox of entrepreneurial education (p. 203); and that entrepreneurship itself should become part of all basic education in the near future. This is the most desirable outcome for every entrepreneurship scholar, and the book's efforts in making all this foundational literature and effectual principles easily accessible are the most effective way of starting with teaching rather than preaching. The book promises a journey, a trip and ultimately this is what it will achieve, building on the motivational underpinnings of entrepreneurial action.

\section{References}

Astebro, T. (2003), 'The Return to Independent Invention: Evidence of Unrealistic Optimism, Risk Seeking or Skewness Loving?', Economic Journal, Vol. 113, Issue 484, pp. 226-239.

Baumol, W. (1990), 'Entrepreneurship: Productive, Unproductive, and Destructive', Journal of Political Economy, Vol. 98, No. 5, pp. 893-921.

Bernardo, A. E. and Welch, I. (2001), 'On the Evolution of Overconfidence and Entrepreneurs', Journal of Economics and Management Strategy, Vol. 10, No. 3, pp. 301-330.

Camerer, C. and Lovallo, D. (1999), 'Overconfidence and Excess Entry: An Experimental Approach', American Economic Review, Vol. 89, No. 1, pp. 306-318.

Cesarini D., Dawes C. T., Johannesson, M., Lichtenstein, P. and Wallace, B. (2009), 'Genetic Variation in Preferences for Giving and Risk Taking', Quarterly Journal of Economics, Vol. 124, No. 2, pp. 809-842.

de Meza, D. and Southey, C. (1996), 'The Borrower's Curse: Optimism, Finance and Entrepreneurship', Economic Journal, Vol. 106, Issue 435, pp. 375-386.

Hayek, F. (1945), 'The Use of Knowledge in Society', American Economic Review, Vol. 35, No. 4, pp. 519-530.

Hurst, E. and Lusardi, A. (2004), 'Liquidity Constraints, Household Wealth, and Entrepreneurship', The Journal of Political Economy, Vol. 112, No. 2, pp. 319-347.

Kahneman, D. and Tversky, A. (1979), 'Prospect Theory: An Analysis of Decision under Risk', Econometrica, Vol. 47, No. 2, pp. 263-291. 
Kihlstrom, R. E. and Laffont, J.-J. (1979), 'A General Equilibrium Entrepreneurial Theory of the Firm Based on Risk Aversion', Journal of Political Economy, Vol. 87, No. 4, pp. 719-48.

March, J. G. (1991), 'Exploration and Exploitation in Organized Learning', Organizational Science, Vol. 2, No. 1, pp. 71-87.

Moskowitz, T. J. and Vissing-Jorgensen, A. (2002), 'The Returns to Entrepreneurial Investment: A Private Equity Premium Puzzle?', American Economic Review, Vol. 92, pp. 745-78.

Nicolaou, N., Shane, S., Cherkas, L., Hunkin, J. and Spector, T. D. (2008), 'Is the Tendency to Engage in Entrepreneurship Genetic?', Management Science, Vol. 54, No. 1, pp. 167-179.

Oosterbeek, H., van Praag, M. and Ijsselstein, A. (2010), 'The Impact of Entrepreneurship Education on Entrepreneurship Skills and Motivation', European Economic Review, Vol. 54, pp. 442-454.

Schumpeter, J. (1934), The Theory of Economic Development. Cambridge, MA: Harvard University Press (First published in German, 1912).

Shane, S. (2004), Academic Entrepreneurship: University Spinoffs and Wealth Creation, Northampton, MA: Edward Elgar Publishing, Inc.

Shane, S. (2008), Illusions of Entrepreneurship, Hartford, CT: Yale University Press.

Shepherd, D. (2003), 'Learning from Business Failure: Propositions of Grief Recovery for the Self-employed'. The Academy of Management Review, Vol. 28, No. 2, pp. 318-328.

Thaler, R. (1985), 'Mental Accounting and Consumer Choice', Marketing Science, Vol. 4, No. 3, pp. 199-214.

Tversky, A. and Kahneman, D. (1991), 'Loss Aversion in Riskless Choice: A Reference Dependent Model', Quarterly Journal of Economics, Vol. 106, No. 4, pp. 1039-1061.

Georgios A. Panos, Essex Business School, UK

\section{HRM to the fore!}

- Pons-Vignon, N. (ed.) (2010), Don't waste the crisis: Critical perspectives for a new economic model, Geneva: ILO, paperback, $\mathfrak{£} 18.00$, 96pp.

- Gall, G. (ed.) (2009), Union Revitalisation in Advanced Economies, Basing-

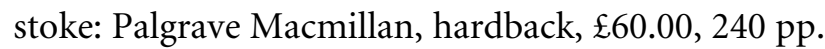

- Gall, G. (ed.) (2009), The Future of Union Organising: Building for Tomorrow, Basingstoke: Palgrave Macmillan, hardback, £60.00, 256pp.

- Benson, J. and Zhu, Y. (eds.) (2010), The Dynamics of Asian Labour Markets: Balancing Control and Flexibility, London and New York, NY: Routledge, hardback, £80.00, 240 pp.

- Brewster, C. J. and Mayrhofer, W. (eds.) (2010), Handbook of Research in Comparative Human Resource Management, Cheltenham: Edward Elgar, hardback, £175.00, 700pp.

'Industrial relations' as an issue has been very much in limbo of late. Compared with the tumultuous 1970s, the number of working days lost through strikes in the UK in recent years has been perhaps only a fraction of what it was back then. In 2009, just under half a million days were lost to strikes, even with a major dispute at the Royal Mail, compared with 29 million in the Winter of Discontent in 1979. So, some may say there is no need to panic, at least not yet. Or is there? There are always exceptions, of course, as we await the social impact of the trenchant cuts in public spending recently set out by the UK Coalition Government. Indeed, some say conflicts of interest among the social partners remain as endemic in modern capitalism as ever- 
Copyright of Journal of General Management is the property of Braybrooke Press Ltd. and its content may not be copied or emailed to multiple sites or posted to a listserv without the copyright holder's express written permission. However, users may print, download, or email articles for individual use. 